Vol. 1 No. 2 September 2021, e-ISSN : 2797-8842 | p-ISSN : 2797-9431

\title{
MENINGKATKAN KEMAMPUAN BERPIKIR KRITIS DALAM PEMBELAJARAN SEJARAH MENGGUNAKAN MODEL PEMBELAJARAN TWO STAY TWO STRAY DENGAN AKTIVITAS WINDOW SHOPPING PADA PESERTA DIDIK XI MIPA 2 DI SMA NEGERI 10 MALANG
}

\author{
ENDANG SETYONINGSIH \\ SMA Negeri 10 Malang \\ Email: ninkendang66@gmail.com
}

\begin{abstract}
ABSTRAK
Penelitian ini bertujuan meningkatkan potensi berpikir kritis dalam pembelajaran sejarah dengan menggunakan model pembelajaran Two Stay Two Tray dengan aktivitas Windaw Shopping pada peserta didik XI MIPA 2 di SMA negeri 10 Malang. Penelitian ini merupakan Penelitian Tindakan Kelas (PTK) yang dilaksanakan dalam dua siklus, setiap siklus dilaksanakan dalam 5 tahap yaitu perencanan, pelaksanaan, pengamatan, evaluasi dan refleksi. Kelas XI MIPA2 SMA Negeri 10 Malang Semester genap Tahun Pelajaran 2018/2019 berjumlah 36 peserta didik. Hasil penelitian menunjukan bahwa pada siklus I hanya ada 15 peserta didik yang memiliki kemampuan merumuskan masalah $(41,66 \%)$, kemampuan mencari informasi dari berbagai sumber dicapai oleh 15 peserta didik $(41,66 \%), 18$ peserta didik memiliki kemampuan merekam hasil diskusi (50\%), sedangkan kemampuan mengomunikasikan dicapai oleh 16 peserta didik (44,44\%). Siklus II menunjukan bahwa ada 27 peserta didik yang memiliki kemampuan merumuskan masalah (75\%), kemampuan mencari informasi dari berbagai sumber dicapai oleh 26 peserta didik ( 72,22\%), 36 peserta didik memiliki kemampuan merekam hasil diskusi (100\%), sedangkan kemampuan mengomunikasikan dicapai oleh 25 Peserta didik (100\%). Berdasarkan perbandingan hasil capaian indikator siklus kesatu dan kedua menggambarkan bahwa pembelajaran dengan menggunakan model pembelajaran Two Stay Two Tray dengan aktivitas Windaw Shopping telah berlangsung dengan baik dan dapat meningkatkan potensi berpikir kritis peserta didik. Rekomendasi dari peneliti untuk penggunaan model pembelajaran Two Stay Two Tray dengan aktivitas Windaw Shopping adalah (1) menginformasikan model kegiatan pembelajaran yang digunakan pada peserta didik lebih awal, agar peserta didik dapat mengikuti langkah-langkah model ini dengan benar, (2) memberi kesempatan peserta didik mencari bahan pengayaan dalam kegiatan diskusi (3) sebaiknya guru sudah memberi arahan link- web yang bisa di rujuk peserta didik dalam mecari sumber informasi di internet agar sumbernya valid atau dapat dipercaya (4) pembentukan kelompok diupayakan memperhatikan pemerataan kemampuan peserta didik.
\end{abstract}

Kata Kunci : Penelitian Tindakan Kelas, Two Stay Two Stray, Window Shopping

\section{ABSTRACT}

This study aims to increase the potential for critical thinking in learning history by using the Two Stay Two Tray learning model with Windaw Shopping activities for XI MIPA 2 students at SMA Negeri 10 Malang. This research is a Classroom Action Research (CAR) which is carried out in two cycles, each cycle is carried out in 5 stages, namely planning, implementing, observing, evaluating and reflecting. Class XI MIPA2 SMA Negeri 10 Malang Even Semester 2018/2019 academic year totaled 36 students. The results showed that in the first cycle there were only 15 students who had the ability to formulate problems $(41.66 \%)$, the ability to find information from various sources was achieved by 15 students $(41.66 \%), 18$ students had the ability to record the results of the discussion. (50\%), while the ability to communicate was achieved by 16 students (44.44\%). Cycle II shows that there are 27 students who have the ability to formulate problems (75\%), the ability to find information from various sources is achieved by 26 students $(72.22 \%), 36$ students have the ability to record the results of discussions $(100 \%)$, while the ability to communicate is achieved by 25 students (100\%). Based on the 
comparison of the results of the first and second cycle indicators, it illustrates that learning using the Two Stay Two Tray learning model with Windaw Shopping activities has been going well and can increase students' critical thinking potential. Recommendations from researchers for the use of the Two Stay Two Tray learning model with Windaw Shopping activities are (1) informing the learning activity model used to students early, so that students can follow the steps of this model correctly, (2) giving students the opportunity students look for enrichment materials in discussion activities (3) the teacher should have provided web-link directions that students can refer to in finding sources of information on the internet so that the source is valid or reliable (4) the formation of groups is sought to pay attention to the equitable distribution of students' abilities.

Keywords: Classroom Action Research, Two Stay Two Stray, Window Shopping

\section{PENDAHULUAN}

Pembelajaran abad 21 merupakan pembelajaran yang dirancang untuk mempersiapkan peserta didik siap mengadapi tantangan. Di era ini kemajuan Teknologi Informasi dan Komunikasi (TIK) yang berkembang begitu cepat memiliki pengaruh terhadap berbagai aspek kehidupan termasuk pada proses belajar mengajar, sehingga pembelajaran tidak lagi terpusat pada pendidik tetapi harus lebih berpusat pada peserta didik. Berikut karakter pembelajaran abad 21 yang sering disebut sebagai 4 C. Menurut Arnyana (2020) yaitu: Communication, Collaboration, Critical Thinking and Problem Solving, Creativity and Innovation). Salah satu ketrampilan yang dikembangkan pada pembelajaran abad 21 adalah Critical Thinking (berpikir kritis). Kemampuan peserta didik untuk memiliki ketrampilan berpikir kritis belum tentu bisa muncul dengan sendirinya tetapi perlu kemampuan guru untuk mampu menggali kemampuan tersebut melalui proses belajar mengajar yang kreatif, inovatif dan menantang agar memunculkan kemampuan berpikir kritis, hal ini bisa dilaksanakan guru dengan melakukan pemilihan model, metode, media pembelajaran yang sesuai dengan kebutuhan peserta didik.

Menurut Johnson (dalam Eka, 2020) berpikir Kritis adalah sebuah proses yang terorganisir dan jelas yang digunakan dalam aktivitas mental seperti pemecahan masalah, pembuat keputusan, menganalisis asumsi dan penemuan secara ilmiah. Menurut Ennins (dalam Rahma, 2017) terdapat 5 kelompok indikator kemampuan berpikir kritis diataranya yaitu: Klarifikasi dasar (Elementery Clarification). Klarifikasi terbagi menjadi 3 indikator yaitu (1) Mengidentifikasi atau merumuskan pertanyaan (2) Menganalisis argument (3) Bertanya dan menjawab pertanyaan yang menantang Sedangkan menurut Zubaidah (dalam Chotimah, 2008 :16) menyatakan berpikir Kritis adalah : Suatu kemampuan yang dimiliki individu untuk melihat dan memecahkan masalah yang ditandai dengan sifat-sifat dan bakat kritis yaitu mempunyai sifat rasa ingin tahu yang tinggi, memiliki daya imajinatif, dan selalu tertantang, berani mengambil resiko dan mempunyai sifat selalu menghargai hak-hak orang lain, arahan bahkan bimbingan orang lain.

Dapat disimpulkan bahwa kemampuan berpikir kritis pada hakikatnya kemampuan peserta didik untuk memiliki kemampuan menalaran yang reflektif, pemecahan masalah, pembuat keputusan, menganalisis asumsi dan penemuan secara ilmiah, kemampuan menganalisis idea Atau gagasan ke arah yang lebih baik. Kemampuan berpikir kritis ini terbentuk akibat dari adanya proses belajar yang mengarah pada kegiatan pembelajaran yang Hight Order Thiking ( HOTS) .

Masalah yang dikaji dalam penelitian ini adalah kenginan guru untuk meningkatan kemampuan peserta didik kelas XI MIPA 2 Di SMA Negeri 10 Malang untuk berpikir kritis, hal ini di sebabkan guru merasa dalam kegiatan pembelajaran kemampuan berpikir kritis peserta didik masih kurang, misalnya kemampuan peserta didik dalam menyusun pertanyaan yang mengarah ke kemampuan Hight Orders Thinking ( HOTs), kemampuan peserta didik mencari sumber yang valid dan kemampuan peserta didik dalam memecahkan masalah. Peserta didik yang memiliki kekurangan menyusun pertanyaan yang Hots disebabkan oleh beberapa hal antara lain peserta didik kurang mau membaca materi terkait dengan bahasan , peserta didik 
enggan mencari sumber yang lebih untuk memecahkan masalah/tugas yang diberikan guru, buku teks peserta didik yang kadang-kadang tidak memuat materi tersebut, sehingga peserta didik kurang memiliki wawasan yang luas. Wawasan yang luas dan kecakapan yang memadai sangat diperlukan dalam mengadapi tantangan di abad 21.

Berdasarkan permasalahan dan penyebab kurangnya kemampuan peserta didik dalam berpikir kritis penulis berusaha untuk meningkatkan kemampuan berpikir kritis melalui proses pembelajaran dengan menggunakan model pembelajaran two stay two stray dengan aktivitas window shopping. Menurut Istianingsih (2017) Aktivitas Window Shopping meminta siswa berjalan-jalan melihat hasil pekerjaan kelompok lain yang ditempelkan di dinding atau di jendela. Kegiatan berkunjung ini tidak hanya melihat-lihat saja tetapi siswa diminta mengamati dan mencatat hasil kerja kelompok lain

Pada penelitian ini yang dimaksud peneliti dengan berpikir kritis adalah potensi atau kemampuan peserta didik memiliki kemampu membuat rumusan masalah yang mengarah ke hight order thingking (HOTs) dan mampu memecahkkan masalah dengan aktif, mencari informasi, mampu merekam hasil diskusi kelompok lain dengan baik dan mampu mengkomunikasikan hasil diskusi.

Kemampuan berpikir kritis harus dimiliki oleh semua peserta didik karena merupakan salah satu tuntutan keberhasilan dalam proses pembelajaran, abad 21 mengapa demikian ? Menurut Redhana (2019) karena perkembangan ilmu pengetahuan yang sangat pesat, adanya tantangan global, peserta didik merupakan agen perubahan,adanya perbedaan pengetahuan yang dimiliki antara suatu warga negara serta agar peserta didik mampu memiliki daya saing yang tinggi dan tidak tergilas oleh jaman

\section{METODE PENELITIAN}

Penelitian ini merupakan penelitian tindakan (action research) yang bertujuan untuk meningkatkan meningkatkan kemampuann berpikir kritis dalam pembelajaran sejarah pada peserta didik XI MIPA 2 di SMA Negeri 10 Malang.Tindakan yang dilakukan adalah dengan menerapkan model pembelajaran two stay two stray dengan aktivitas window shopping . Rancangan yang digunakan adalah model rancangan yang diadaptasi Stephen Kemmis dan Mc. Taggart (dalam Somawati, 2021) dengan menggunakan dua siklus, masing-masing siklus terdiri dari empat tahapan yaitu: (1) perencanaan, (2) tindakan, (3) observasi dan evaluasi, dan (4) Refleksi. Yang menjadi subjek penelitian ini peserta didik kelas XI MIPA 2 yang berjumlah 36 orang, yang terdiri atas: 13 orang peserta didik laki-laki dan 23 orang peserta didik perempuan. Sedangkan yang menjadi objek penelitian adalah kemampuan berpikir kritis peserta didik dalam pelajaran sejarah Indonesia. Penelitian dilakukan pada semester Genap Tahun Pelajaran 2018/2019. Pemilihan lokasi penelitian kelas XI MIPA 2 karena peserta didik pada kelas tersebut (1) kurang aktif dalam pembelajaran (2) Peserta didik kurang mampu membuat pertanyaan yang mengarah ke ranah HOTS (3) Peserta didik kurang mampu memecahkan masalah melalui sumber-sumber belajar yang dapat di percaya (4) Peserta didik kurang berani mengomunikasikan hasil diskusi

\section{HASIL DAN PEMBAHASAN}

\section{Hasil penelitian}

\section{a. Siklus 1}

Pelaksanaan siklus I dilaksanakan dua (2) kali pembelajaran , pada Selasa tanggal 15 Januari dan 29 Januari 2019 Jam 3 dan 4. Langkah awal yang dilakukan guru memberikan materi "Peran tokoh-tokoh nasional dan daerah dalam perjuangan menegakkan negara Republik Indonesia"

Selanjutnya menugaskan peserta didik untuk membentuk kelompok dan peserta didik dipersilahkan memperhatikan prosedur dan penerapan langkah-langkah model pembeajaran Two Stay Two stray dengan aktivitas Window Shopping, pelaksanaan pembelajaran dimulai dengan langkah sesuai dengan kegiatan pembelajaran dalam RPP 
Untuk melihat keberhasilan dalam melakukan pengamatan peneliti menentukan indikatorindikator yang relevan dengan metode diskusi. Indikator itu antara lain (1) Kemampuan merumuskan masalah,(2) keaktifan dalam mencari informasi, (3) kemampuan merekam hasil informasi dari kelompok lain, (4) kemampuan mengomunikasika pada kelompok asal. Selama pelaksanaan diskusi peneliti melakukan pengamatan dan mencatat hasilnya ke dalam table ( Terlampir ) dan memasukan dalam prosentasi keberhasil.

Hasil pengamatan pada siklus I ini dapat dikategorikan sebagai berikut.

Tabel 1. Capain Indikator Siklus I

\begin{tabular}{|c|c|c|c|c|}
\hline No & Indikator & $\begin{array}{l}\text { Jumlah } \\
\text { Peserta didik } \\
\text { Berpartisipasi }\end{array}$ & $\begin{array}{l}\text { Persentase } \\
\text { Capaian }\end{array}$ & $\begin{array}{l}\text { Kriteria } \\
\text { Capaian }\end{array}$ \\
\hline 1. & $\begin{array}{l}\text { Kemampuan } \\
\text { merumuskan masalah }\end{array}$ & 15 & $41,66 \%$ & Cukup \\
\hline 2. & $\begin{array}{lr}\text { Kemampuan mencari } \\
\text { informasi } & \text { dari } \\
\text { berbagai sumber } & \end{array}$ & 15 & $41,66 \%$ & Cukup \\
\hline 3. & $\begin{array}{l}\text { Kemampuan merekam } \\
\text { hasil diskusi }\end{array}$ & 18 & $50,00 \%$ & Cukup \\
\hline 4. & $\begin{array}{l}\text { Kemampuan } \\
\text { mengomunikasikan } \\
25 \text { Peserta didik }\end{array}$ & 16 & $64 \%$ & Cukup \\
\hline
\end{tabular}

Dari data di atas secara umum dapat direfleksikan bahwa peningkatan kemampuan berpikir kritis dengan model pembelajaran two stay two stray dengan aktivitas Window shopping pada siklus I ini belum bisa dilaksanakan secara maksimal, ini bisa dilihat pada hasil pengamatan peneliti dan observer sebagai berikut :

Hasil temuan observasi siklus I :

a. Peserta didik tidak semuanya aktif dalam pembelajaram

b. Peserta didik yang aktif kebanyakan peserta didik putri

c. Tidak semua peserta didik mampu mengomunikasikan hasil informasi yang diperoleh saat melakukan shopping ke toko-toko peserta lain

d. Penempelan hasil kerja kelompok terlalu berdekatan sehingga peserta didik berjubel untuk megunjungi mal/ took/ galeri kelompok lain

e. Berjubelnya peserta didik pada saat mengunjugi mal/toko membuat beberapa peserta didik bergurau dan tidak mendengarkan penjelasan dari penjaga toko

Penyebab munculnya permasalahan yang mengakibatkan model pembelajaran two stay two stray dengan aktivitas Window shopping tidak dapat berjalan seperti yang harapkan antara lain:

a. Peserta didik kebanyakan masih bingung apa yang harus dilakukan, karena belum terbiasa dengan model pembelajaran two stay two stray dengan aktivitas Window shopping sedangkan mereka diberi batasan waktu untuk langkah-langkah pembelajarannya, meskipun guru sudah memberikan arahan sebelumnya

b. Peserta didik dalam kegiatan mengomunikasikan hasil kulakan/pembelian ilmu dari toko kelompok lain, tidak semuanya membacakan hasil diskusinya tetapi hanya menyerahkan pada penulis untuk disalin pada lembar kerja kelompok, padahal harapan peneliti, peserta didik mengemukakan hasil diskusinya pada teman yang lainnya merupakan upaya proses pembelajaran.

c. Penempelan hasil kerja kelompok yang dianggap sebagai toko/ mal untuk shopping ilmu terlalu berdekatan sehingga peserta didik berjubel ketika mengunujungi toko tersebut, akibatnya beberapa siswa tidak fokus mendengarkan informasi dari penjaga toko tetapi justru bergurau dengan temannya 
Berdasarkan hasil capaian dan refleksi pelaksanaan siklus satu ditemukan beberapa kelemahan dan penyebab munculnya kelemahan yang mengakibatkan proses pembelajaran dengan model two stay two stray dengan aktivitas Window shopping tidak dapat berjalan sesuai dengan yang diharapkan. Merujuk pada kelemahan dan penyebabnya maka dilakukan perbaikan perencanaan dan proses pembelajaran pada siklus II.

\section{b. Siklus II}

Langkah awal peneliti mengulas hasil siklus I, memberikan motivasi-motivasi serta penguatan untuk menumbuhkan rasa percaya diri dan lebih focus dalam kegiatan pembelajaran. Materi untuk siklus II yaitu "Menganalisis peristiwa proklamasi kemerdekaan dan maknanya bagi kehidupan sosial, budaya, ekonomi, politik dan pendidikan bangsa Indonesia “.

Pada proses ini peneliti merencanakan tindakan perbaikan yang mengacu pada kelemahan yang muncul pada siklus I, yaitu:

a. Peneliti menjelaskan kembali langkah-langkah pembelajaran menggunakan model two stay two stray dengan aktivitas Window shopping serta memberikan contoh, agar peserta didik tidak bingung lagi dengan tugas yang harus dilakukan berkaitan dengan tanggung jawabnya

b. Memperbanyak sumber belajar terutama buku paket dengan cara meminjam ke kelas lain karena materi ini tercantum dalam buku teks peserta didik

c. Peneliti mewajibkan peserta didik untuk membacakan hasil shopping ilmu dari toko-toko/ mal/kelompok lain ketika kembali ke kelompok asal, tidak boleh diserahkan begitu saja pada sekretaris atau ketua karena dalam proses ini peserta didik sudah mengalami proses belajar.

d. Peneliti memberi instruksi agar penempelan hasil kerja kelompok di beri jarak sehingga peserta didik tidak berjubel saat megunjungi mal atau toko.

Pelaksanaan pembelajaran siklus II pada hari Senin, tanggal 11 Februari dan 25 Februari 2019 jam 3 dan 4. Tahap pelaksanaan pada siklus II ini sama dengan siklus I yaitu : Sesuai dengan rencana pembelajaran yang ada pada kegiatan belajar mengajar dalam RPP dengan langkah-langkah: Pembagian kelompok, penugasan kelompok, menyusun rumusan masalah,memecahkan masalah, Kegiatan selanjutnya dilakukan pembagian tugas , Setelah kegiatan berbelanja, menyalin tugas kelompok, peserta didik ditugaskan untuk mengerjakan UKBM cek pemahaman kegiatan 1! UKBM SEJ-3.7/4.7/4/1.1, guru berkeliling memberikan bimbingan dan penilaian, guru menutup pelajaran.

Berdasarkan hasil pengamatan pada siklus II ini sudah banyak terjadi perubahan, hal ini bisa dilihat pada banyaknya peserta didik yang menunjukkan keaktifan selama kegiatan pembelajaran berlangsung.

Secara umum pelaksanaan diskusi pada siklus II sudah berjalan sesuai yang diharapkan. Mayoritas peserta didik sudah mulai aktif dalam pembelajaran , baik pada saat menyusun rumusan masalah, memecahkan masalah melalui berbagai sumber, merekam informasi saat shopping ilmu ke toko lain dan mengomunikasikan hasil shopping ilmu ke kelompok asal. Jika pada siklus pertama jalannya menyusun rumusan masalah, kemampuan mencari informasi, merekam informasi dan mengomunikasikan peserta didik masih katagori cukup pada siklus II para peserta didik sudah ada peningkatan dalam menyususn rumusan masalah yang Hots, peserta didik asyik mencari informasi dari berbagai sumber belajar masing-masing kemudian mendiskusikan hasil temuanya dengan anggota lainnya, selain itu pada tahap merekam informasi mereka berusaha untuk menulis hasil temuannya dengan baik pada lembar kerja , dan melakukan kegiatan mengomunikasikan pada kelompok asal secara bergantian, bahkan mereka mengulang mengomukasikan semua permasalahan yang diberikan guru pada masing-masing kelompok secara kronologis sehingga semua kelompok memahami materi yang dibahas pada hari itu. Diakhir kegiatan ketika perwakilan mengomunikasikan hasil kerja kelompok mayoritas peserta didik berusaha untuk mendengarkan secara serius bahkan berusaha melakukan pencatatan di buku masing-masing. Setelah kegiatan pembelajaran selesai peneliti memberi 
tugas peserta didik untuk menyelesaikan UKMB : cek pemahaman kegiatan 1! UKBM SEJ3.7/4.7/4/1.1

Hasil kegiatan pembelajaranpada siklus II ini dapat dipaparkan sebagai berikut.

Tabel 2. Capain Indikator Siklus II

\begin{tabular}{|l|l|c|c|l|}
\hline No & Indikator & $\begin{array}{l}\text { Jumlah } \\
\text { Peserta didik } \\
\text { Berpartisipasi }\end{array}$ & $\begin{array}{l}\text { Persentase } \\
\text { Capaian }\end{array}$ & $\begin{array}{l}\text { Kriteria } \\
\text { Capaian }\end{array}$ \\
\hline 1. & $\begin{array}{l}\text { Kemampuan } \\
\text { membuat rumusan } \\
\text { masalah yang } \\
\text { mengarah ke } \\
\text { penalaran }\end{array}$ & 27 & $75,00 \%$ & Baik \\
\hline 2. & $\begin{array}{l}\text { Kemampuan } \\
\text { mencari informasi } \\
\text { berbagai sumber }\end{array}$ & 26 & $72,22 \%$ & Baik \\
\hline 3. & $\begin{array}{l}\text { Kemampuan } \\
\text { merekam hasil } \\
\text { diskusi }\end{array}$ & 36 & $100 \%$ & Baik \\
\hline 4. & $\begin{array}{l}\text { Kemampuan } \\
\text { mengomunikasikan } \\
\text { (pembeli Ilmu 25 } \\
\text { orang ) }\end{array}$ & 25 & Baik \\
\hline
\end{tabular}

Dari data di atas secara umum dapat direfleksikan bahwa kemampuan berpikir kritis dengan metode model two stay two stray dengan aktivitas Window shopping pada siklus II ini sudah dapat berjalan seperti yang diharapkan oleh peneliti, karena indikator-indikator yang ditetapkan sudah tercapai ( katagori baik ). Hal ini bisa dilihat pada hasil pengamatan peneliti dan observer sebagai berikut :

a. Proses pembelajaran model two stay two stray dengan aktivitas Window shopping berjalan secara baik, semua peserta didik dapat berpartisipasi aktif dalam menyususn rumusan masalah yang mengarah ke pemikiran kritis sesuai tugas masing-masing

b. Sebagian besar peserta didik berperan aktif dalam kegiatan mencari informasi dari berbagai sumber belajar baik dari buku teks maupun internet untuk memecahkan masalah dan mendiskusikannya dengan teman dalam kelompok

c. Mulai munculnya keinginan peserta didik untuk melakukan perekaman informasi secara baik serta berani mengomunikasikan pada teman dikelompok asal dengan penuh percaya diri. Hal ini disebabkan karena peserta didik sudah menguasaai materi secara mendalam

d. Munculnya kesadaran peserta didik untuk tidak tergantung pada orang lain dalam memecahkan masalah yang menjadi tanggung jawabnya karena masing-masing peserta didik memiliki sumber belajar secara mandiri.

\section{Pembahasan}

\section{a. Kemampuan berpikir Kritis}

Berdasarkan hasil observasi dan catatan lapangan dan data hasil evaluasi diperoleh data pada siklus II secara umum sudah sesuai harapan, karena pada indicator kemampuan berpiki kritis ada $27(75,00 \%)$ peserta didik yang mampu membuat pertanyaan yang tingkat penalaran baik pada pembahasan materi maupun pada saat diskusi, ada $26(72,22 \%)$ peserta didik yang aktif mencari informasi, ada $36(100,00 \%)$ yang mampu merekam hasil informasi dari kelompok lain dengan benar dan ada $25(100,00 \%)$ peserta didik yang melakukan tindakan mengomunikasikan pada kelompok asal. Dari data di atas akan penulis diskripsikan sebagai berikut: 
1) Indikator kemampuan membuat rumusan masalah

Capaian indicator kemampuan membuat rumusan masalah yang hots termasuk katagori baik, karena ada peningkatan jumlah peserta didik yang nampak mampu menyusun pertanyaan yang kritis semula $41.66 \%$ (15 peserta didik ) menjadi $75 \%$ (27 peserta didik) Hal ini menunjukkan bahwa peserta didik mulai tumbuh keterampilan berpikir kritis, karena rasa ingin tahu yang tinggi, berusaha memahami hal-hal yang melatar belakangi suatu peristiwa terjadi, dampaknya pemahaman terhadap materi menjadi lebih baik.

Menurut Ennins (dalam Rahma, 2017) terdapat 5 kelompok indicator kemampuan berpikir kritis diataranya yaitu : Klarifikasi dasar ( Elementery Clarification ). Klarifikasi dasar terbagi menjadi 3 indikator yaitu (1) Mengidentifikasi atau merumuska pertanyaan (2) Menganalisis argument (3) Bertanya dan menjawab pertanyaan yang menantang two stay two stray denga aktivitas Window shopping menurut Devy (2015) menyatakan, Struktur two stay two stray yaitu memberi kelompok untuk membagikan hasil dan informasi dengan kelompok lain, untuk membagikan hasil pada kelompok lain masing-masing kelompok harus ada kemampuan dalam merumuskan masalah/pertanyaan agar informasi yang diberikan pada kelompok lain runtut dan kronologis. Pada penelitian ini terutama pada siklus II kemampuan peserta didik dalam kegiatan merumuskan masalah/pertanyaan yang mengarah pada kemampuan berpikir tingkat tinggi sangat meningkat, hal ini nampak pada rumusan masalah/ pertanyaan yang di konsultasikan pada guru merupakan pertanyaan membutuhan jawaban yang perlu adanya penalaran, selain itu pertanyaan yang diajukan oleh peserta didik yang bertamu pada kelompok lain juga menunjukan pertanyaan yang mengarah berpikir tingkat tinggi, dimana jawaban dari pertanyaan tersebut membutuhkan kemampuan bernalar dengan demikian maka model pembelajaran two stay two stray dengan aktivitas Window shopping dapat meningkatkan kemampuan peserta didik dalam membuat rumusan masalah/pertanyaan yang mengarah pada kemampuan berpikir kritis.

2) Kemampuan mencari informasi dari berbagai sumber

Capaian indicator mencari informasi termasuk katagori baik, karena ada peningkatan jumlah peserta didik yang melakukan kegiatan mencari informasi baik melalui buku teks maupun sumber internet pada saat pembagian tugas untuk memecahkan masalah di kelompoknya pada lembar kerja berjalan dengan baik, peserta didik yang semula hanya mengandalkan internet saja, sudah ada keinginan membaca buku teks untuk menambah wawasannya. Pada siklus II ini mereka mencari informasi dengan baik, kegiatan mencari informasi ini semula hanya ada 15 peserta didik atau 41,66\% menjadi 26 peserta didik atau $72,22 \%$. Hal ini menunjukan bahwa kemampuan mencari informasi peserta didik mengalami peningkatan sebab peserta didik merasa lebih siap dalam kegiatan pencarian informasi , kesiapan peserta didik dalam kegiatan ini didukung oleh ketersediaan materi sumber belajar dan alokasi waktu yang cukup. Menurut Juhji \& Suardi (2018) Ciri-ciri berpikir kritis adalah : (1) memiliki rasa ingin tahu yang tinggi (2) memiliki ternik bertanya yang mengarah pada kemampuan Hots (3) berusaha mencari informasi dengan baik.

Sedangkan menurut Ennins (dalam Rahma, 2017) terdapat 5 kelompok indicator kemampuan berpikir kritis diataranya yaitu : Klarifikasi dasar yang meliputi merumuskan pertanyaan (2) Menganalisis pendapat yang dimiliki (3) Bertanya dan menjawab pertanyaan yang menantang. Berdasarkan pendapat Ennins dan Sumadi mengenai ciri- ciri berpikir kritis disimpulkan bahwa berpikir kritis adalah kegiatan mencari pernyataan yang jelas mengenai suatu pertanyaan, berusaha mencari informasi dengan baik,,mencari sumber yang memiliki kredibilitas, mampu memecahkan masalah dengan jawaban yang mendalam, dan memiliki keterbukaan dalam berpikir.

Model pembelajaran Stay two Stray dengan aktivitas Window Shopping menurut Isjoni (dalam Nurhidayah, 2018 ) TSTS berasal dari bahasa Inggris yang berarti dua tinggal dua tamu. Kegitan bertamu bertujuan untuk mencari informasi dari kelompok lain. Pada penelitian siklus II sangat nampak keaktifan peserta didik dalam mencari informasi pada kelompok lain hal ini dapat di lihat dari keruntutan hasil kerja kelompok yang di kumpulkan untuk dinilai guru, selain 
itu juga nampak pada keseriusan peserta didik saat mendengarkan informasi dari kelompok yang di kunjungi, dapat disimpulkan bahwa Model pembelajaran two stay two stray denga aktivitas Window shopping dapat meningkatkan kemampuan peserta didik untuk mencari informasi yang memiliki kredibilitas baik.

3) Indikator kemampuan merekam informasi

Capaian indicator merekam informasi termasuk katagori baik, karena ada peningkatan jumlah peserta didik yang melakukan kegiatan perekaman informasi pada saat pelaksanaan diskusi di kelompok lain pada lembar kerja dengan baik, peserta didik yang semula hanya menulis asal-asalan, pada siklus dua ini mereka merekam dengan baik , kegiatan merekam informasi ini semula hanya ada 18 peserta didik atau 50\% menjadi 36 peserta didik atau100\%. Hal ini menunjukan bahwa kemampuan merekan informasi peserta didik mengalami peningkatan sebab peserta didik merasa lebih siap dalam kegiatan perekaman informasi , juga karena adanya informasi guru yang akan menilai catatan peserta didik ,kesiapan peserta didik dalam kegiatan ini didukung pula oleh kondisi kelas yang kondusif dan alokasi waktu yang cukup.

Menurut Devy (2015) Asumsi yang digunakan sebagai acuan dalam pengembangan model pembelajaran Kooperatif tipe two stay two stray ini, sebagai berikut: (1) Membutuhkan kemampuan kerja tim (kelompok) secara kooperatif (2) Untuk melatih keterampilan berpikir kritis peserta didik. (3) Meningkatkan motivasi dan hasil belajar siswa. (4) Siswa dituntut untuk memiliki tanggungjawab dan aktif. Peserta didik dituntut untuk memiliki tanggung jawab terhadap tugas yag menjadi tanggunga jawabnya, pada kegiatan bertamu peserta didik harus merekam semua informasi yang di perolah dari kelompok lain yang di kunjungi dan menyampaikan hasil informasi pada kelompok asal secara lesan dan tulisan. Pada siklus II kemampuan peserta didik dalam merekam informasi sangat baik terlihat pada Lembar Kerja Kelompok untuk bertamu terisi sesuai dengan informasi dari kelompok tempat bertamu dengan baik, dapat disimpulkan bahwa Model pembelajaran two stay two stray denga aktivitas Window shopping dapat meningkatkan kemampuan peserta didik dalam merekam hasil diskusi/ informasi dengan baik

4) Indikator Mengomunikasikan hasil diskusi

Capaian indikator mengomunikasikan hasil diskusi termasuk katagori baik dalam siklus ini, karena semula hanya ada 16 orang peserta didik atau $64 \%$ yang melakukan kegiatan mengomunikasikan hasil diskusi pada kelompok asal, menjadi meningkat semua peserta didik yang bertugas sebagai pembeli ilmu yaitu 25 peserta didik atau $100 \%$. Hal ini dipengaruhi oleh rasa percaya diri peserta didik mulai tumbuh karena mereka memahami materi yang harus di kuasai pada kegiatan belajar mengajar, selain itu peserta didik mulai sadar dan paham secara mendalam materi yang harus dikuasai yang menjadi tanggung jawabnya, maka ketika menyampaikan informasi pada teman dikelompoknya dengan tenang dan penuh percaya diri.. Selain itu guru mengintruksi agar peserta didik yang bertugas membeli ilmu mengomunikasikan hasilnya pada kelompok asal dengan cara dibacakan tidak boleh diserahkan begitu saja pada ketua atau sekretaris.

Menurut Lie (dalam Widiastuti, 2015) Model pembelajaran two stay two stay ini merupakan salah satu bentuk kerja kelompok yang anggotanya empat orang, dua orang bertugas menerima tamu yang datang bertamu, sedangkan dua lainnya akan berkunjung ke kelompok lain guna mencari informasi lebih lanjut mengenai tugas yang menjadi tanggung jawab kelompok. .Jadi dapat disimpulkan bahwa model pembelajran two stay two stray adalah model pembelajaran yang memberi kesempatan kepada kelompok untuk membagikan hasil informasi dengan kelompok lainnya.Pada penelitian ini nampak pada siklus II peserta didik yang bertugas menjaga toko menyampaikan hasil diskusi kelompoknya pada para pembeli ilmu/ para tamu dengan penuh percaya diri dan sangat menguasai materi kelompoknya, juga ketika peserta didik yang bertugas mencari ilmu kembali pada kelompok asal peserta didik juga menyampaikan hasil rekaman informasinya pada kelompok asal dengan cara lesan dengan baik dengan 
demikian model pembelajaran two stay two stray dengan aktivitas window shopping dapat meningkatkan kemampuan mengomunikasikan hasil diskusi.

Agar lebih jelas dapat dilihat pada tabel perbandingan capaian hasil indikator Siklus I dan Siklus II sebagai Berikut :

Tabel 3. Perbandingan Capaian Indikator Siklus I dan II

\begin{tabular}{|l|l|l|l|l|l|}
\hline & No & Indikator & Siklus I & \multicolumn{2}{l|}{ Siklus II } \\
\cline { 3 - 6 } & & Persentase & Katagori & Persentase & Katagori \\
\hline 1. & $\begin{array}{l}\text { Kemampuan } \\
\text { membuat rumusan } \\
\text { masalah } \\
\text { mengarah } \begin{array}{r}\text { yang } \\
\text { penalaran }\end{array}\end{array}$ & $41,66 \%$ & Cukup & $75,00 \%$ & Baik \\
\hline 2. & $\begin{array}{l}\text { Kemampuan } \\
\text { mencari informasi } \\
\text { pada kelompok lain }\end{array}$ & $41,66 \%$ & Cukup & $72,22 \%$ & Baik \\
\hline 3. & $\begin{array}{l}\text { Kemampuan } \\
\text { merekam hasil } \\
\text { diskusi }\end{array}$ & $50,00 \%$ & Cukup & $100, \%$ & Baik \\
\hline 4. & $\begin{array}{l}\text { Kemampuan } \\
\text { mengomunikasikan } \\
\text { ( Pembeli ilmu 25 } \\
\text { orang ) }\end{array}$ & $44,44 \%$ & Cukup & $100 \%$ & Baik \\
\hline
\end{tabular}

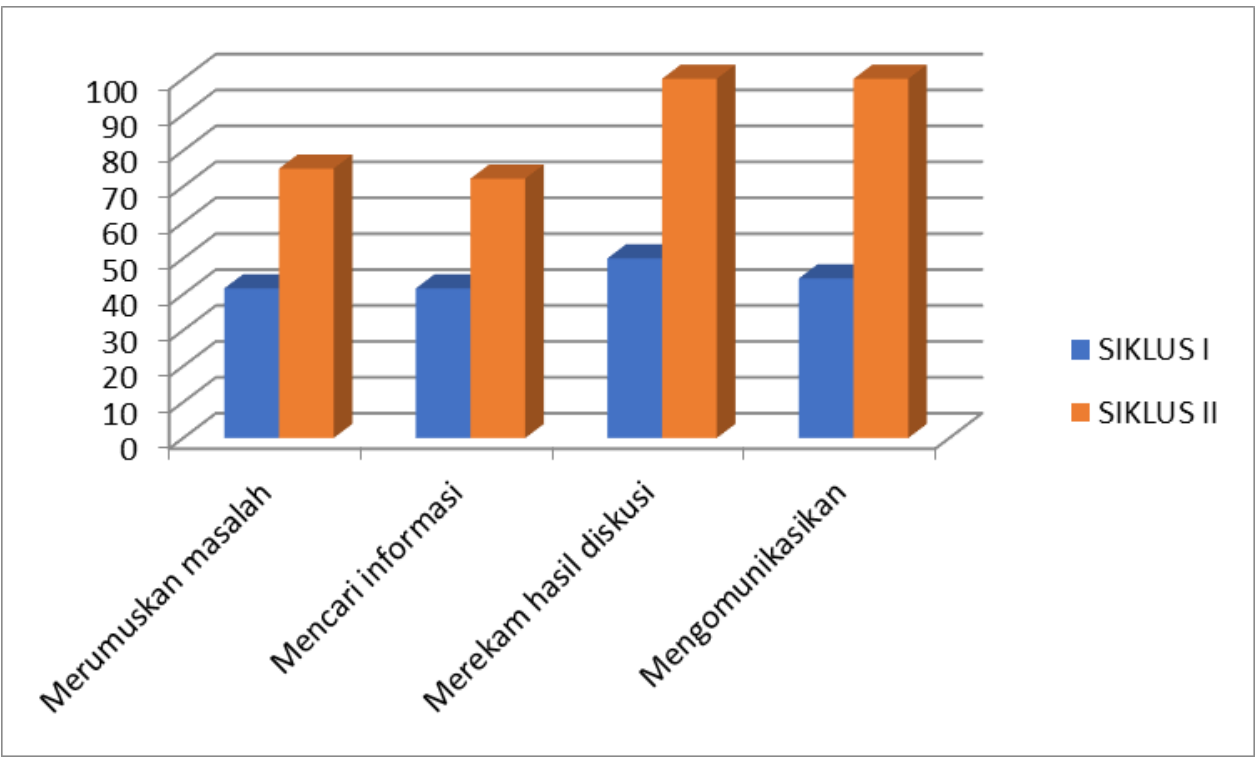

Gambar 1. Perbandingan Capaian Indikator Siklus I dan II

Dari data di atas secara umum dapat simpulkan bahwa kemampuan berpikir kritis dengan metode model two stay two stray dengan aktivitas window shopping pada siklus II ini sudah dapat berjalan seperti yang diharapkan oleh peneliti, karena indikator-indikator yang ditetapkan sudah tercapai (katagori baik). Dengan demikian model pembelajaran two stay two stray dengan aktivitas Window shopping dapat meningkatkan kemampuan keterampilan berpikir kristis.

\section{KESIMPULAN}

Pelaksanaan penelitian tindakan kelas yang dilaksanakan di kelas XI MIPA 2 SMA Negeri 10 Malang dengan menggunakan metode kooperatif Model two stay two stray dengan aktivitas window shopping ini dilaksanakan dalam 2 siklus. Pada siklus II kegiatan sudah berjalan sesuai dengan rancangan sehingga mampu menumbuhkan rasa percaya diri peserta didik dalam 
kegiatan pembelajar karena mereka memiliki kemampuan berpikir kritis dan mampu menguasai materi secara mendalam. Hal ini dapat dibuktikan melaui hasil pengamatan peneliti bahwa semua indikator kemampuan berpikir kritis mengalami peningkatan dengan katagori baik.

\section{DAFTAR PUSTAKA}

Arnyana, I. B. P. (2019). Pembelajaran untuk meningkatkan kompetensi 4c (communication, collaboration, critical thinking dancreative thinking) untuk menyongsong era abad 21. Konferensi Nasional Matematika dan IPA Universitas PGRI Banyuwangi, 1(1), i-xiii.dari https://ejournal.unibabwi.ac.id/index.php/knmipa/article/view/829

Chotimah,Husnul (2008). Meningkatkan Hasil Belajar Biologi dan Kemampuan berpikir Kritis Peserta Didik Kelas X-5 SMA Laboratorium Universitas Negeri Malang Melalui Model Pembelajaran Cooperative Script. PTK. SMA Laboratorium Universitas Negeri Malang.

Eka, I. J., Awanita, I. M., \& Irawan, I. K. A. (2020). Pola Program Berpikir Kritis (Critical Thinking) dalam Ruang Belajar Mengajar Era Abad 21. Jurnal PASUPATI, 7(1), 5971.

Istianingsih, K.,\& Mir'anina, R. (2018). Pengaruh Model Two Stay Two Stray dengan Aktivitas Window Shopping Terhadap Minat dan Hasil Belajar Siswa MTS Al-Muttaqin Plemahan Kediri. Jurnal Ilmiah Pendidikan Matematika Volume 3 Nomor 2. 92 - 98.

Juhji, J., \& Suardi, A. (2018). Profesi Guru Dalam Mengembangkan Kemampuan Berpikir Kritis Peserta Didik Di Era Globalisasi. Geneologi PAI: Jurnal Pendidikan Agama Islam, 5(1), 16-24.

Kirana, D. G. (2015). Penerapan Model Pembelajaran Two Stay Two Stray Dalam Meningkatkan Keaktifan Dan Kemampuan Komunikasi Belajar Matematika (PTK Pada Siswa Kelas VII Semester Genap SMP N 1Ngemplak 2014/2015) .Disertasi. Universitas Muhammadiyah Surakarta.

Nurhidayah, A. (2018). Perbandingan Metode Think Pair And Share Dan Two Stay Two Stray Terhadap Hasil Belajar (Penelitian Quasi Eksperimen Tema 1 Indahnya Kebersamaan Subtema 1 Keberagaman Budaya Bangsaku di Kelas IV SDN 223 Bhakti Winaya). Disertasi. FKIP UNPAS..

Rahma, S. (2017). analisis berpikir kritis siswa dengan pembelajaran Socrates kontekstual di smp negeri 1 padangratu lampung tengah. Disertasi. UIN Raden Intan Lampung.

Redhana,I.W.(2019).Mengembangkan Keterampilan Abad Ke-21 Dalam Pembelajaran Kimia. Jurnal Inovasi Pendidikan Kimia, 13(1).

Somawati,N.W.(2021). Penerapan Model Pembelajaran Group Investigation Untuk Meningkatan Hasil Belajar Peserta Didik Kelas IX.4 Semester I SMP Negeri 1 Banjarangkan Tahun Pelajaran 2019/2020. Jurnal Inovasi Penelitian Pendidikan dan Pembelajaran, 1(1), 1-8.

Widiastuti, Eva. (2015). Penerapan Model Pembelajaran Two Stay Two Stray Terhadap Minat Dan Hasil Belajar Siswa Kelas VII MTS N 02 Semarang. Skripsi. Universitas Negeri Semarang. 